We regret to be obliged to call attention to these serious defects in what might have been made a useful book. We still more" regret to think that this volume, owing to Mrs. Marcet's excellent name, will find its way into families and schools; many will thus gain their only knowledge of science from a volume which contains not only many obsolete phrases, but which also omits all reference to the conservation of energy or the correlation of the physical forces.

W. F. B.

\section{THE GEOLOGICAL SURVEY OF OHIO}

Geological Survey of Ohio. Report of Progress in 1870, by J. S. Newberry, Chief Geologist, including Reports by the Assistant Geologists, Chemists, and Local Assistants. (Columbus: Nevin and Myers, State Printers, r87 r, pp. 568.)

THE labours of Prof. Newberry and his colleagues during the year 1870 have resulted in the accumulation of a great many details relating chiefly to the structure of that portion of the great Appalachian Coal-field which extends over a considerable part of Ohio. Without the aid of a good map it is somewhat difficult to follow the descriptions given in this Report, the numerous local references and details having a tendency to bewilder the reader. This, however, is unavoidable under the circumstances; and those who desire to obtain a full and clear conception of the geological structure of Ohio will have to wait the completion of the map and final report promised by Dr. Newberry, the present volume not pretending to be more than its title implies. Nevertheless, it contains a very large and varied amount of information, which will, no doubt, be duly appreciated by those for whom it has been prepared. Especially noteworthy are the numerous illustrative sections of Carboniferous strata, and analyses of coals, ironstones, fireclays, and soils, as also two ably written sketches "On the Present State of the Manufacture of Iron in Great Britain," and "On the State of the Steel Industry," both of which will repay perusal by those of us here who are interested in these matters.

Scattered through the purely geological portion of the Report are many points of interest, which arrest attention as one glances over the pages. Thus we are told that "at Zaleski, in mining the Nelsonville coal, a fine boulder of grey quartzite was found half imbedded in the coal, and the other half in the overlying shale. The quartzite is very hard, and the boulder was rounded and worn by friction before it came to the coal." It measured I 7 in. by 12 in., and had adhering to it in places bits of coal and black slate which showed a slickensided surface. The stone appeared to have settled into the coal when the latter was in a soft state. Prof. Newberry speculates with diffidence on the possibility of the boulder having been "brought down by river ice from some higher and colder part of the old continent, which was skirted by the coal-producing lowlands." In connection with this it is somewhat interesting to find that a local deposit of quartz conglomerate occurs here and there underneath and skirting the coal-strata, and is believed by Dr. Newberry to represent an old beach of the period. From some such gravel and shingle deposit the boulder may have been transported, but whether by means of ice, water-plant, or land-plant, who shall tell?

Another exceedingly interesting and readable portion of the Report is the "Agricultural Survey," by Mr. J. H. Klippart, in which the writer discusses, amongst other subjects (such as prairies, forests, \&c.), the origin of the soils in certain districts of the State. Those geologists who believe in the former existence during the Glacial epoch of mild interglacial periods will find much here to support their opinion. We are told that the succession of the Drift materials, beginning with the oldest, is as follows :-

a Glacial drift.

$b$ Erie clays.

$c$ Forest bed.

$d$ Iceberg drift.

$e$ Alluvium.

$f$ Peat, calcareous tufa, shell marl.

The oldest deposit is believed to be the product of landice, and the presence of the Erie clays betokens that after the disappearance of the great glaciers, wide sheets of fresh-water overspread some districts of the State. The forest bed (consisting of roots, trunks, branches, and leaves of such trees as sycamore, beech, hickory, and red cedar) shows that by-and-by the fresh-water basins were in some places filled up, and the new soil covered with an abundant forest-growth. After this came a period of de pression, when great deposits of gravel and sand gathered over the surface of the drowned land, and large boulders and erratics were floated by ice from the north.

These and other matters of interest and importance will, no doubt, be fully treated of in the final report, which is to consist of four volumes, the first two being devoted to the geology and palæontology of the State, the third to its economic geology, and the fourth to its agriculture, botany, and zoology. A large collection of fossils has been made, many species being new to science. It is to be hoped that the good people of Ohio will not grudge the money that will be required for the adequate representation and description of these remains, but that when published the final report will be found in every way as complete as those admirable works which have been issued by other States of the Union. Professor Newberry seems to have little doubt that it will be so, for he thinks that the value and significance of fossils are coming to be generally appre. ciated. "There are, however," he says, "yet some intelligent men, even editors and members of legislature, who cherish the notion that there is nothing which has any value in this world but that thing which has a dollar in it, and that so plainly visible as to be seen by them. Such men, to quote the language of one of them, 'don't care a row of pins for your clams and salamanders, but want something practical." This "practical " man must surely have been related to that colonial official who is said to have objected strongly to the expense of "engraved portraits of extinct bugs and beetles," as he irreverently styled certain Silurian fossils. But the day of such wiseacres has gone past, and it may be confidently expected that Dr. Newberry and his colleagues will have no difficulty in getting the necessary funds voted for the completion of their important Survey.
J. G. 